\title{
A trait-based approach to the conservation of threatened plant species
}

\author{
Juan C. Álvarez-Yépiz, Alberto Búrquez
}

Angelina Martínez-Yrízar and Martin Dovciak

\begin{abstract}
Traditionally the vulnerability of threatened species to extinction has been assessed by studying their environment, genetics and population dynamics. A more comprehensive understanding of the factors promoting or limiting the long-term persistence of threatened species could be achieved by conducting an analysis of their functional responses to changing environments, their ecological interactions, and their role in ecosystem functioning. These less traditional research areas can be unified in a trait-based approach, a recent methodological advance in ecology that is being used to link individual-level functions to species, community and ecosystem processes to provide mechanistic explanations of observed patterns, particularly in changing environments. We illustrate how trait-based information can be translated into well-defined conservation strategies, using the example of Dioon sonorense, an Endangered cycad endemic to north-western Mexico. Scientific information yielded by trait-based research, coupled with existing knowledge derived from well-established traditional approaches, could facilitate the development of more integrative conservation strategies to promote the long-term persistence of individual threatened species. A comprehensive database of functional traits of threatened species would be of value in assisting the implementation of the trait-based approach.
\end{abstract}

Keywords Biodiversity loss, conservation strategies, cycad, Dioon sonorense, Endangered species, Mexico, plant conservation, rarity

\section{Introduction}

The vulnerability of species to extinction has traditional1 ly been assessed within three major areas of study:

Juan C. Álvarezz-Yépiz ${ }^{*} \dagger$ (Corresponding author), Alberto Búrquez and Angelina Martinez-Yrízar Instituto de Ecología, Universidad Nacional Autónoma de México, Colosio y Sahuaripa, Col. Los Arcos, Hermosillo, Sonora 83250, Mexico. E-mail yepiz@fulbrightmail.org

MARTin Dovciak State University of New York College of Environmental Science and Forestry, Syracuse, New York, USA

${ }^{*}$ Also at: State University of New York College of Environmental Science and Forestry, Syracuse, New York, USA

$\dagger$ Also at: Instituto Tecnológico de Sonora, Obregón, Sonora, Mexico

Received 27 August 2017. Revision requested 26 January 2018.

Accepted 13 June 2018. First published online 12 February 2019. environment, genetics and population dynamics (Gilpin \& Soulé, 1986), hereafter referred to as the traditional approach. In this context, the study of environment includes investigating the quality and quantity of available and potential habitat, and thus all aspects of species' relationships with abiotic and biotic factors. Genetic studies focus on the genetic diversity of species and populations (including adaptation to change) and population bottlenecks from small effective population sizes. Research on population dynamics investigates species' demography and persistence in a given environment manifested via population structure, fecundity and, ultimately, fitness. The traditional approach has proved successful in studies of threatened and nonthreatened plant and animal species (e.g. Oostermeijer et al., 2003; Conard, 2009; Kalkvik, 2012). However, other components of a more comprehensive assessment of the viability of populations (some of these originally proposed by Gilpin \& Soulé, 1986), such as species' functional responses to a changing environment, their ecological interactions, and their role in ecosystem functioning, have not been formally incorporated into conservation research, particularly regarding threatened taxa (Schemske et al., 1994). These additional research areas can be unified in a traitbased approach, a recent methodological advance in ecology that is being used to link individual-level functions (measured with functional traits) to species, community and ecosystem processes, to provide mechanistic explanations for the observed patterns, particularly in changing environments (McGill et al., 2006; Violle et al., 2007; Garnier \& Navas, 2012; Shipley et al., 2016).

From the perspective of trait-based ecology, a trait is 'any morphological, physiological or phenological feature measurable at the individual level, from the cell to the wholeorganism level, without reference to the environment or any other level of organization' (Violle et al., 2007). These traits are called functional traits when they influence fitness through their effects on growth, reproduction and survival, which are the three components of individual performance (Violle et al., 2007). Species traits are usually assessed as mean values of individual traits per population, and such values can vary with the environment. Thus, information on the local environment of populations is needed to interpret the ecological and evolutionary meaning of measured traits and to make useful predictions under changing environmental conditions (McGill et al., 2006; Violle et al., 2007; Garnier \& Navas, 2012; Shipley et al., 2016). 
Trait-based ecology is a relatively new discipline that is increasingly used in studies of community assembly (e.g. Ackerly \& Cornwell, 2007), biotic interactions (e.g. Wardle et al., 1998) and ecosystem functioning (e.g. Díaz \& Cabido, 2001), and in predicting species' responses to climate warming (e.g. Diamond et al., 2012). Chown (2012) presented a trait-based framework for use in conservation, specifically in conservation physiology, to forecast the risk of climate and habitat changes to species and higher ecological levels (communities, ecosystems). A major challenge of the traitbased approach to conservation is the identification and measurement of functional traits relevant to individual threatened species, particularly those traits related to responses to changing environments, species' ecological interactions, and ecosystem functioning. Here we propose and illustrate how a functional trait-based approach can be used to increase our understanding of the vulnerability of threatened species to extinction. We introduce the steps and structure for implementing a trait-based approach in the conservation of threatened species, and illustrate this approach in a case study of Dioon sonorense, an Endangered cycad endemic to north-western Mexico, including a discussion of the potential applicability of the trait-based approach in guiding the conservation of this species.

\section{A trait-based approach to the conservation of threatened plant species}

By definition, threatened species are already at risk of extinction as a result of species-specific extrinsic and intrinsic factors. A more complete understanding of species' vulnerability to extinction requires knowledge not only of their environment, genetics and demography but also of functional traits related to their responses to changing environments, their interactions and their role in ecosystem functioning (Gilpin \& Soulé, 1986; Oostermeijer et al., 2003; Chown, 2012). This information can be translated into more integrative management strategies to increase the viability of threatened species (Fig. 1). We focus on illustrating the conceptual importance of studying functional traits to inform the conservation of threatened species rather than on the methodological peculiarities of measurement and analysis of functional traits, which can be found elsewhere (e.g. Díaz et al., 2007; Bernhardt-Römermann et al., 2008; Kraft \& Ackerly, 2010; Pérez-Harguindeguy et al., 2013).

We synthesized basic information from published studies for both the traditional approach and the trait-based approach, to illustrate how these approaches differ and how they can be useful in guiding the conservation of a target threatened species (Table 1). The information for the trait-based approach can be formalized as a series of distinct and well-defined activities required to gather scientific information on the functional traits and factors most likely

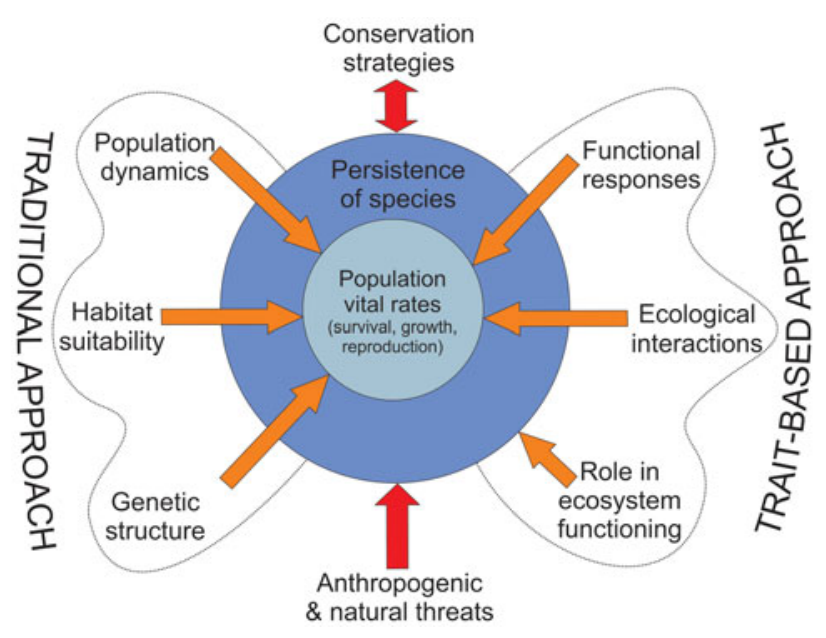

FIg. 1 How the trait-based approach complements the traditional approach to the conservation of threatened species. The traditional approach focuses on species population dynamics, habitat suitability and genetic structure, and has provided essential information for guiding conservation strategies for threatened species. The trait-based approach has been formally included in conservation research to a lesser extent, even though it can provide information on physiological responses to environmental variability and ecological interactions of species, and their roles in ecosystem functioning (which may indirectly influence species persistence). Combining these approaches may lead to more integrative conservation strategies to promote the long-term persistence of target species exposed to anthropogenic and natural threats. There is a dynamic feedback (double arrow) between conservation strategies and species persistence, as they can affect each other.

to affect population fitness and species persistence, and thus facilitate science-based species conservation (Table 1). Although the collected information should be speciesspecific, a multi-species framework by phylogenetic group may also be possible when related species display parallel responses to similar threats.

Our case study illustrates how the trait-based approach can provide information to understand (1) the individual physiological responses to environmental stress imposed by water, light and nutrient limitations that may be caused by the changing environment (e.g. Álvarez-Yépiz et al., 2014a; Williams et al., 2014; Díaz-Álvarez et al., 2015; Urban, 2015), (2) the importance of maintaining species' ecological interactions (e.g. plant-plant, plant-pollinator/seed disperser, and plant-herbivore), as the loss of these interactions usually results in species extinctions (e.g. Tilman et al., 1994; Álvarez-Yépiz et al., 2014b; Valiente-Banuet et al., 2015), and (3) the importance of the role of individual species in ecosystems, because threatened species can increase carbon storage, biomass accumulation and ecosystem stability by increasing plant functional diversity, facilitating a broader use of available resources (Lyons et al., 2005; Mouillot et al., 2013; Álvarez-Yépiz \& Dovčiak, 2015; Leitão et al., 2016). 
TABLE 1 Summary of the main steps for implementing a trait-based approach (steps 5-7) that complements the traditional approach (steps 1-4) for the conservation of threatened plant species.

\begin{tabular}{|c|c|}
\hline Step & Description \& goals \\
\hline $\begin{array}{l}\text { (1) Reviewing literature on the life history \& } \\
\text { ecology of the target species }\end{array}$ & $\begin{array}{l}\text { Existing information is a cost-effective means of directing research towards filling in } \\
\text { existing knowledge \& data gaps; knowledge of the biology of the target species can be used } \\
\text { to direct conservation \& management \& future conservation research, particularly } \\
\text { information on (a) why the target species is threatened, rare or endemic, (b) the main } \\
\text { extrinsic \& intrinsic threats to the target species, \& (c) the species' responses to key biotic } \\
\text { \& abiotic environmental limiting factors. }\end{array}$ \\
\hline (2) Monitoring population dynamics & $\begin{array}{l}\text { Following populations \& cohorts of individuals within populations through time helps to } \\
\text { determine if populations are declining, stable or increasing, \& to identify the life stages } \\
\text { that contribute most to population growth (Álvarez-Yépiz et al., 2011). }\end{array}$ \\
\hline (3) Evaluating habitat suitability & $\begin{array}{l}\text { Typifying \& analysing habitats across populations of various sizes can increase our } \\
\text { understanding of resource limitations (e.g. soil nutrients, water, light) \& identify new } \\
\text { potentially suitable habitats for reintroduction (Álvarez-Yépiz et al., 2011). }\end{array}$ \\
\hline (4) Assessing genetic diversity & $\begin{array}{l}\text { Long-term population viability can be determined by population size, genetic structure \& } \\
\text { diversity. Genetic analysis of populations of various sizes \& life stages (seed, seedling, } \\
\text { juvenile \& adult) can provide information about dispersal distances, gene flow, popula- } \\
\text { tion history \& the main population reservoirs of genetic diversity (González-Astorga } \\
\text { et al., 2008). }\end{array}$ \\
\hline (5) Measuring functional responses & $\begin{array}{l}\text { Physiological traits can help to detect thresholds of species' tolerance to resource lim- } \\
\text { itations \& environmental stressors (e.g. temperature, water or nutrient stress) at different } \\
\text { life stages \& improve the understanding \& prediction of species' responses to changing } \\
\text { environments (Âlvarez-Yépiz et al., 2014b). }\end{array}$ \\
\hline (6) Quantifying ecological interactions & $\begin{array}{l}\text { As species interactions occur throughout their life cycles it is important to identify the } \\
\text { relationships between threatened species \& other taxa (e.g. with pollinators, seed dis- } \\
\text { persers, herbivores or nurse plants) \& quantify them at various demographic stages; it is } \\
\text { also important to identify keystone threatened species \& their cascade effects } \\
\text { (Álvarez-Yépiz et al., 2014a). }\end{array}$ \\
\hline $\begin{array}{l}\text { (7) Ascertaining the species' role in ecosystem } \\
\text { functioning }\end{array}$ & $\begin{array}{l}\text { Functional trait analysis can be useful to identify the individual function of threatened } \\
\text { species \& scale this up to the ecosystem level; e.g. the trait-based approach can help to } \\
\text { determine the role of the target threatened species in ecosystem stability \& resilience, or in } \\
\text { other processes, such as carbon storage \& nutrient cycling (Álvarez-Yépiz \& Dovčiak, } \\
\text { 2015). }\end{array}$ \\
\hline
\end{tabular}

\section{A trait-based approach for the cycad Dioon sonorense}

\section{Description of the target species}

Cycads are one of the most threatened groups of vascular plants (Donaldson, 2003; IUCN, 2017). These gymnosperms evolved c. 300 million years ago and were widespread during the Jurassic but declined dramatically during the mass extinction of the Cretaceous, when they apparently contracted to rocky or nutrient-poor marginal habitats (Norstog \& Nicholls, 1997; Crisp \& Cook, 2011; IUCN, 2017). Many cycad species occur in small, isolated populations in tropical and subtropical regions, often in marginal rocky habitats, where they can obtain nitrogen through symbiotic $\mathrm{N}_{2}$-fixing cyanobacteria (Norstog \& Nicholls, 1997; Lindblad \& Costa, 2002; Álvarez-Yépiz et al., 2014a).

Dioon sonorense (De Luca, Sabato \& Vasquez Torres, Zamiaceae) is a cycad species endemic to the arid lands of north-western Mexico (essentially to the state of Sonora, Fig. 2). It is an evergreen, long-lived understorey species of the northernmost tropical dry forest of the Americas and is valued as an ornamental plant (Plate 1). There are five confirmed localities where this species still occurs, in c. 50 subpopulations, mostly restricted to subtropical vegetation (Fig. 2). Each locality contains 5-20 subpopulations, usually with 10-100 mature individuals each but frequently with $<30$ (González-Astorga et al., 2008; Álvarez-Yépiz et al., 2011). The total estimated population size is c. 2,400 mature individuals, with an apparent decreasing population trend since the 1960s (Chemnick \& Gregory, 2010). Dioon sonorense is dioecious, and female plants under optimal conditions produce a single cone (strobilus) every 2 years, which restricts its regeneration potential and population persistence (Norstog \& Nicholls, 1997; Álvarez-Yépiz et al., 2011). It is categorized as Endangered on the IUCN Red List (Chemnick \& Gregory, 2010). This species is exposed to (1) extrinsic threats, including illegal collecting (seeds, whole plants), land-use change (land clearing, grazing), and extreme natural events (hurricanes, fires, frosts), and (2) intrinsic threats, including small adult population sizes, little or no recruitment to the adult stage, and a 


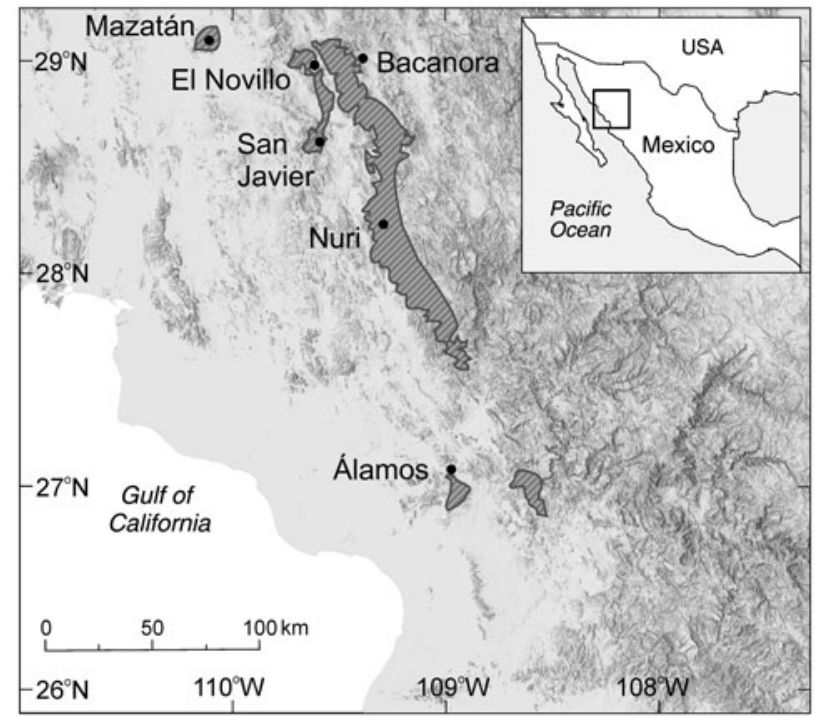

FIG. 2 The five confirmed localities (black dots) of the cycad Dioon sonorense in the state of Sonora, Mexico, and one (San Javier) where it is locally extinct; and the potential distribution of the species (hatched, following elevations of 750-1,250 m), based on past and present known occurrences (González-Astorga et al., 2008; Álvarez-Yépiz et al., 2011). The species does not occur in the wild elsewhere.

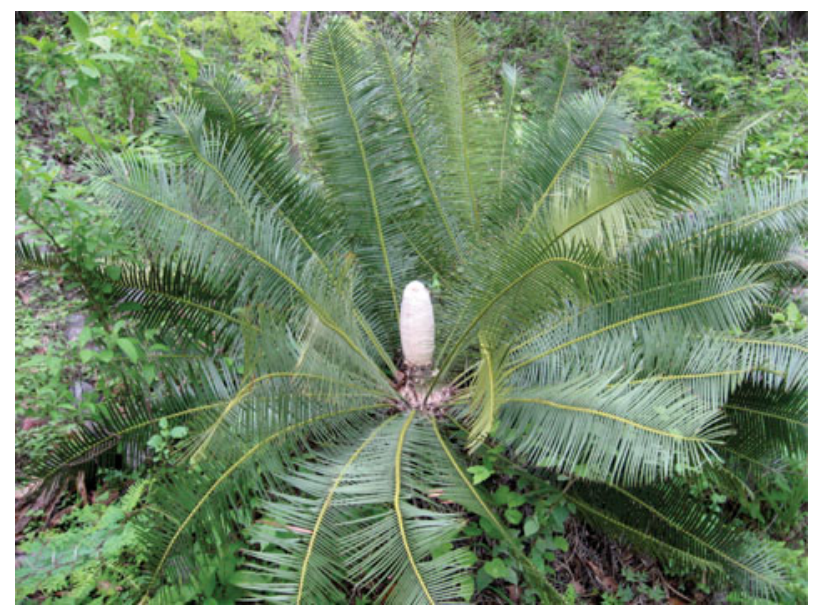

Plate 1 A male individual of the Endangered cycad Dioon sonorense, a long-lived species with a narrow geographical range in north-western Mexico (Fig. 2). Photograph by J.C. Álvarez-Yépiz.

distribution restricted to marginal habitats (Norstog \& Nicholls, 1997; González-Astorga et al., 2008; Chemnick \& Gregory, 2010; Álvarez-Yépiz et al., 2011).

\section{Description of the trait-based approach}

Any contributions of a trait-based approach (or any other new approach) should be evaluated in terms of what new information or insight it yields relative to the traditional (or previously used) research approaches. For example, the traditional approach has produced key scientific insights about $D$. sonorense population dynamics, habitat suitability and genetic structure. A matrix analysis indicated decreasing finite population growth rates $(\lambda<1)$ for small populations ( $<30$ adults; Álvarez-Yépiz et al., 2011), with larger population sizes ( $\geq 50$ adults) required for population stability $(\lambda$ c. 1$)$ or growth $(\lambda>1)$. Values of $\lambda$ of o.86-1.047 have been reported for other, more abundant cycad species (Raimondo \& Donaldson, 2003; PérezFarrera et al., 2006). Elasticity analysis indicated that adults contribute most to population growth rates (ÁlvarezYépiz et al., 2011), similar to other cycads and longlived plant species in general (Silvertown et al., 1996; Raimondo \& Donaldson, 2003). Habitat analyses indicated that $D$. sonorense may occur in low abundance on poor soils where angiosperm competition is low, but it can reach higher abundance, recruitment and population growth on more fertile soils where nurse plants can ameliorate heat stress and poor soil conditions (Bertness \& Callaway, 1994; Álvarez-Yépiz et al., 2011, 2014b). Genetic analyses indicated that the species has a robust genetic structure (high genetic diversity, slightly positive global inbreeding and zero local inbreeding; González-Astorga et al., 2008), and thus a good genetic baseline for conservation.

The traditional approach to conservation has not, however, provided detailed information on the species functional or physiological responses to environmental variability, ecological interactions or the species roles in ecosystem functioning that may influence its persistence. As discussed below, some key traits of $D$. sonorense that have been identified as important because of their effect on population vital rates and broader ecosystem functions include physiological (e.g. high water-use efficiency and symbiotic $\mathrm{N}_{2}$ fixation, which increase the efficiency of resource use), morphological (e.g. sclerophylly, which decreases water loss and increases protection against herbivory), and phenological traits (e.g. evergreen leaves, which increase nutrient retention).

Functional traits related to water conservation and nutrient acquisition are particularly important in D. sonorense because they can affect population vital rates in the waterand nutrient-limited habitats where this species occurs. Dioon sonorense seems to be able to access more atmospheric nitrogen at sites with low soil fertility through symbiotic associations with cyanobacteria, and this ability increases with ontogeny (Álvarez-Yépiz et al., 2014a). Seedlings of $D$. sonorense (and other species in this genus) are especially vulnerable to seasonal drought, with higher water loss leading to lower water-use efficiency (i.e. the ratio of photosynthesis to transpiration rates) and subsequently higher seedling mortality as a result of desiccation (Álvarez-Yépiz et al., 2014a; but see also Yáñez-Espinosa et al., 2014; 
Yáñez-Espinosa \& Flores, 2016). Sclerophylly in leaves of $D$. sonorense seedlings is a trait that helps them to reduce water loss (by transpiration) and, at least in seedlings, requires 60 days to develop fully (Álvarez-Yépiz et al., 2014a). Therefore, reducing light intensity through artificial shading or protection from nurse plants should increase seedling survival, especially during the first few months of development.

Important ecological interactions of $D$. sonorense with other species include facilitation by angiosperms, which can be especially important at the seedling stage, when the angiosperm canopy provides shade that reduces transpiration and increases water-use efficiency and seedling survival (Álvarez-Yépiz et al., 2014a,b; but see also YáñezEspinosa et al., 2014; Yáñez-Espinosa \& Flores, 2016). However, the growth and survival of $D$. sonorense at different life stages vary with the identity of neighbouring plants (Álvarez-Yépiz et al., 2014b); for example, intraspecific competition is strongest at the seedling stage, especially in sheltered microsites densely colonized by cycad seedlings, whereas interspecific competition is strongest at the adult stage. The type of neighbour (conspecific vs heterospecific) and associated neighbourhood interactions (competition, facilitation) have important conservation implications, as they can be used to guide the selection of appropriate microsites for seedling establishment for species restoration or reintroduction. For example, rocky areas with conspecific canopies tend to facilitate the survival of $D$. sonorense seedlings by reducing interspecific competition (Álvarez-Yépiz et al., 2014b), and thus they may be suitable sites for successful conservation or reintroduction efforts attempting to increase the number of populations. Conservation strategies accounting for species interactions may include maintaining or promoting greater canopy cover to protect seedlings from heat and drought stress. However, subsequent management should reduce canopy cover (e.g. via silviculture) to decrease interspecific competition and promote recruitment of juveniles into adults, especially in productive sites with denser canopies. Other biotic interactions that are important in cycads but unknown for $D$. sonorense include relationships with herbivores, pollinators, seed dispersers and $\mathrm{N}_{2}$-fixing cyanobacteria (Norstog \& Nicholls, 1997; Pérez-Farrera et al., 2006; Snow \& Walter, 2007; Hall \& Walter, 2013).

Key ecosystem functions such as carbon storage can be disproportionately enhanced locally by threatened species such as D. sonorense (e.g. Álvarez-Yépiz \& Dovčiak, 2015; Leitão et al., 2016) because rare species often possess unique combinations of functional traits that increase functional diversity and resource use (Lyons et al., 2005; Mouillot et al., 2013; Álvarez-Yépiz et al., 2017). The evergreen and longlived habit of $D$. sonorense implies the species contributes to the regional carbon pool and cycling through longer-term carbon storage (for hundreds of years) and slow carbon release. In tropical dry forest stands where $D$. sonorense occurs, up to $20 \%$ of the above-ground biomass has been attributed to this species (Álvarez-Yépiz \& Dovčiak, 2015). In addition, $D$. sonorense may facilitate the survival of other species by providing permanent shade as a result of its evergreen nature, reducing heat and drought stress, thus contributing to the maintenance of biodiversity in tropical dry forests (Álvarez-Yépiz et al., 2014a,b).

\section{Discussion}

The trait-based research approach can provide key information to better understand the persistence mechanisms of a threatened species. Examples of relevant trait-based information in our $D$. sonorense case study highlight that (1) seedlings (especially those with immature leaves, $<60$ days old) rather than juveniles or adults are most sensitive to resource limitation and environmental conditions, making seedling functional responses particularly important for species range shifts as a result of changing climate (Álvarez-Yépiz et al., 2014a,b); (2) relatively low water-use efficiency of seedlings coupled with the lack of microclimatic amelioration by nurse plants contributes to high seedling mortality rates, reduced adult recruitment and consequently reduced population viability (Álvarez-Yépiz et al., 2014a,b; Yáñez-Espinosa et al., 2014; Yáñez-Espinosa \& Flores, 2016); and (3) large populations with many mature individuals contribute locally to the maintenance of ecosystem function and stability by augmenting long-term carbon storage and functional diversity (Álvarez-Yépiz \& Dovčiak, 2015).

The information gathered from the trait-based research approach coupled with existing knowledge derived from the traditional approach can help us define more integrative conservation actions. For example, (1) guarding the most favourable habitats, especially where $D$. sonorense co-occurs with appropriate nurse plants; (2) protecting adult plants across all populations, given their importance for maintaining long-term population viability, genetic and functional diversity, and ecosystem functioning; (3) increasing seedling survival to larger size classes by augmenting canopy shading during early seedling development; (4) managing for lower canopy cover at the juvenile and adult stages to reduce the negative effects of interspecific competition; and (5) producing seedlings of both the threatened target species and its nurse plant species (if necessary) for their reintroduction into suitable habitats, or for augmenting their small natural populations. It may also be necessary to identify and assess the role of local and long-distance dispersers of pollen and seeds, to protect them. All of the above guidelines could be implemented in all five tropical dry forest localities where D. sonorense occurs in Mexico (Fig. 2). However, the habitat of this species is under official protection in only one of the localities, Alamos (through the federal ecological reserve Sierra de Alamos-Rio Cuchujaqui, which is also 
included in UNESCO's Man and the Biosphere Programme). Paradoxically, the populations that require more active conservation management do not have permanent monitoring, as they occur outside the reserve, thus emphasizing the need to designate new protected areas and to work with local communities to increase public awareness in unprotected areas.

The steps used to implement a trait-based approach coupled with the traditional approach for conservation of $D$. sonorense may be applicable to other cycads, especially those of the genus Dioon; the 13 species of Dioon in Mexico exhibit similar population dynamics, habitat preferences and responses to threats (Vovides, 1990; Norstog \& Nicholls, 1997; Yáñez-Espinosa et al., 2014). The value of including the trait-based approach as an additional conservation tool is particularly important considering that, despite the long history of conservation efforts, $21 \%$ of all known vascular plant species are currently considered to be threatened with extinction (RBG Kew, 2016; IUCN, 2017). Some taxonomic groups are particularly at risk; for example, $82 \%$ of cycad species and $31 \%$ of cacti are categorized as threatened on the IUCN Red List (Donaldson, 2003; Goettsch et al., 2015). The trait-based approach can be a valuable methodology for guiding the conservation of threatened species (sensu IUCN, 2012), especially given the freely accessible, extensive global databases of functional traits available for many plant species (Kattge et al., 2011). A comprehensive database of functional traits of threatened species would be particularly helpful in assisting the implementation of the trait-based approach. This approach goes beyond species' intrinsic values, as it emphasizes the responses of functional species to changing environments, and species' functions within ecosystems, providing useful new information that complements traditional research approaches to species conservation.

Acknowledgements JCÁY is grateful for the support from Fulbright-Garcia Robles (\#15086997), and Doctoral (\#214564) and Postdoctoral (\#179045) fellowships from Consejo Nacional de Ciencia y Tecnología. Additional funding was provided by PROFAPI-ITSON, Dence Fellowship, PLACA and Pack summer research grants to JCÁY, and by PAPIIT DGAPA-UNAM \#IN207315 to AMY. ABM and AMY thank the Dirección General de Asuntos del Personal Académico-Programa de Apoyos para la Superación del Personal Académico de la Universidad Nacional Autónoma de México for a sabbatical fellowship at the University of Arizona. Enriquena Bustamante provided technical assistance.

Author contributions Formulation of original idea, writing and revision of article: JCÁY; writing and revision: MD; contribution of ideas, revision of article: $\mathrm{AB}$ and $\mathrm{AMY}$.

\section{Conflicts of interest None.}

Ethical standards This research complied with the Oryx Code of Conduct for authors.

\section{References}

Ackerly, D.D. \& Cornwell, W.K. (2007) A trait-based approach to community assembly: partitioning of species trait values into within- and among-community components. Ecology Letters, 10, 135-145.

Álvarez-Yépiz, J.C., Búrquez, A. \& Dovčiak, M. (2014a) Ontogenetic shifts in plant-plant interactions in a rare cycad within angiosperm communities. Oecologia, 175, 725-735.

Álvarez-Yépiz, J.C., Búrquez, A., Martínez-Yrízar, A., Teece, M., Yépez, E.A. \& Dovciak, M. (2017) Resource partitioning by evergreen and deciduous species in a tropical dry forest. Oecologia, $183,607-618$.

Álvarez-Yépiz, J.C., Cueva, A., Dovčiak, M., Teece, M. \& Yepez, E.A. (2014b) Ontogenetic resource-use strategies in a rare long-lived cycad along environmental gradients. Conservation Physiology, 2, couo34.

Álvarez-Yépiz, J.C. \& DovČiak, M. (2015) Enhancing ecosystem function through conservation: threatened plants increase local carbon storage in tropical dry forests. Tropical Conservation Science, 8, 999-1008.

Álvarez-Yépiz, J.C., Dovčiak, M. \& Búrquez, A. (2011) Persistence of a rare ancient cycad: effects of environment and demography. Biological Conservation, 144, 122-130.

Bernhardt-Römermann, M., Römermann, C., Nuske, R., Parth, A., Klotz, S., Schmidt, W. \& Stadler, J. (2008) On the identification of the most suitable traits for plant functional trait analyses. Oikos, 117, 1533-1541.

Bertness, M.D. \& Callaway, R. (1994) Positive interactions in communities. Trends in Ecology \& Evolution, 9, 191-193.

Chemnick, J. \& Gregory, T. (2010) Dioon sonorense. In The IUCN Red List of Threatened Species 2010: e.T42130A10661262. Http://dx. doi.org/10.2305/IUCN.UK.2010-3.RLTS.T42130A10661262.en. [accessed 25 August 2018].

CHown, S.L. (2012) Trait-based approaches to conservation physiology: forecasting environmental change risks from the bottom up. Philosophical Transactions of the Royal Society B, 367, $1615-1627$.

Conard, J.M. (2009) Genetic variability, demography, and habitat selection in a reintroduced elk (Cervus elaphus) population. $\mathrm{PhD}$ thesis. Kansas State University, Manhattan, USA.

CRISP, M.D. \& Cook, L.G. (2011) Cenozoic extinctions account for the low diversity of extant gymnosperms compared with angiosperms. New Phytologist, 192, 997-1009.

Diamond, S.E., Nichols, L.M., McCoy, N., Hirsch, C., Pelini, S.L., SAnders, N.J. et al. (2012) A physiological trait-based approach to predicting the responses of species to experimental climate warming. Ecology, 93, 2305-2312.

Díaz, S. \& Cabido, M. (2001) Vive la différence: plant functional diversity matters to ecosystem processes. Trends in Ecology \& Evolution, 16, 646-655.

Diaz, S., Lavorel, S., De Bello, F., Quétier, F., Grigulis, K. \& RoBSON, T.M. (2007) Incorporating plant functional diversity effects in ecosystem service assessments. Proceedings of the National Academy of Sciences of the United States of America, 104, 2068420689.

Díaz-Álvarez, E.A., Lindig-Cisneros, R. \& de la Barrera, E. (2015) Responses to simulated nitrogen deposition by the neotropical epiphytic orchid Laelia speciosa. PeerJ, 3, e1021.

Donaldson, J.S. (2003) Cycads. Status Survey and Conservation Action Plan IUCN/SSC. Cycad Specialist Group, IUCN, Gland, Switzerland.

Garnier, E. \& Navas, M.L. (2012) A trait-based approach to comparative functional plant ecology: concepts, methods and 
applications for agroecology. A review. Agronomy for Sustainable Development, 32, 365-399.

Gilpin, M.E. \& Soulé, M.E. (1986) Minimum viable populations: processes of species extinction. In Conservation Biology. The Science of Scarcity and Diversity (ed. M.E. Soulé), pp. 13-34. Sinauer Associates, Sunderland, USA.

Goettsch, B., Hilton-Taylor, C., Cruz-Piñón, G., Duffy, J.P., Frances, A., Hernández, H.M. et al. (2015) High proportion of cactus Species threatened with extinction. Nature Plants, 1, 15142.

González-Astorga, J., Vovides, A.P., Cabrera-Toledo, D. \& Nicolalde-Morejón, F. (2008) Diversity and genetic structure of the Endangered cycad Dioon sonorense (Zamiaceae) from Sonora, Mexico: evolutionary and conservation implications. Biochemical Systematics and Ecology, 36, 891-899.

Hall, J.A. \& Walter, G.H. (2013) Seed dispersal of the Australian cycad Macrozamia miquelii (Zamiaceae): are cycads megafauna-dispersed "grove forming" plants? American Journal of Botany, 100, 1127-1136.

IUCN (2012) IUCN Red List Categories and Criteria: Version 3.1. 2nd edition. IUCN, Gland, Switzerland and Cambridge, UK.

IUCN (2017) The IUCN Red List of Threatened Species. Version 2017-1. Http://www.iucnredlist.org [accessed 4 August 2017].

KalKVIK, H.M. (2012) Conservation and population biology: genetics, demography and habitat requirements of the Atlantic coast beach mice. PhD thesis. University of Central Florida, Orlando, USA.

Kattge, J., Díaz, S., Lavorel, S., Prentice, I.C., Leadley, P., BÖNisCH, G. et al. (2011) TRY - a global database of plant traits. Global Change Biology, 17, 2905-2935.

Kraft, N.J.B. \& ACKerly, D.D. (2010) Functional trait and phylogenetic tests of community assembly across spatial scales in an Amazonian forest. Ecological Monographs, 80, 401-422.

Leitão, R.P., Zuanon, J., Villéger, S., Williams, S.E., Baraloto, C., Fortunel, C. et al. (2016) Rare species contribute disproportionately to the functional structure of species assemblages. Proceedings of the Royal Society of London B, 283, 20160084.

Lindilad, P. \& Costa, J.-L. (2002) The cyanobacterial-cycad symbiosis. Biology \& Environment Proceedings of the Royal Irish Academy, 102, 31-33.

Lyons, K.G., Brigham, C.A., Traut, B.H. \& Schwartz, M.W. (2005) Rare species and ecosystem functioning. Conservation Biology, 19, 1019-1024.

McGill, B.J., Enquist, B.J., Weiher, E. \& Westoby, M. (2006) Rebuilding community ecology from functional traits. Trends in Ecology \& Evolution, 21, 178-185.

Mouillot, D., Bellwood, D.R., Baraloto, C., Chave, J., Galzin, R., Harmelin-Vivien, M. et al. (2013) Rare species support vulnerable functions in high-diversity ecosystems. PLOS Biology, 11, e1001569.

Norstog, K.J. \& Nicholls, T.J. (1997) The Biology of Cycads. Cornell University Press, New York, USA.

Oostermeijer, J.G.B., Luijten, S.H. \& Den Nijs, J.C.M. (2003) Integrating demographic and genetic approaches in plant conservation. Biological Conservation, 113, 389-398.

Pérez-Farrera, M.A., Vovides, A.P., Octavio-Aguilar, P., González-Astorga, J., de la Cruz-Rodríguez, J., Hernández-Jonapá, R. \& Villalobos-Méndez, S.M. (2006)
Demography of the cycad Ceratozamia mirandae (Zamiaceae) under disturbed and undisturbed conditions in a biosphere reserve of Mexico. Plant Ecology, 187, 97-108.

Pérez-Harguindeguy, N., Díaz, S., Garnier, E., Lavorel, S., Poorter, H., Jaureguiberry, P. et al. (2013) New handbook for standardised measurement of plant functional traits worldwide. Australian Journal of Botany, 61, 167-234.

Raimondo, D.C. \& Donaldson, J.S. (2003) Responses of cycads with different life histories to the impact of plant collecting: simulation models to determine important life history stages and population recovery times. Biological Conservation, 111, 345-358.

RBG KEW (2016) The State of the World's Plants Report-2016. Royal Botanic Gardens, Kew, Richmond, UK.

Schemske, D.W., Husband, B.C., Ruckelshaus, M.H., Goodwillie, C., Parker, I.M. \& Bishop, J.G. (1994) Evaluating approaches to the conservation of rare and endangered plants. Ecology, 75, 584-606.

Shipley, B., De Bello, F., Cornelissen, J.H.C., Laliberté, E., Laughlin, D.C. \& Reich, P.B. (2016) Reinforcing loose foundation stones in trait-based plant ecology. Oecologia, 180, 923-931.

Silvertown, J., Franco, M. \& Menges, E. (1996) Interpretation of elasticity matrices as an aid to the management of plant populations for conservation. Conservation Biology, 10, 591-597.

SNOW, E.L. \& WALter, G.H. (2007) Large seeds, extinct vectors and contemporary ecology: testing dispersal in a locally distributed cycad, Macrozamia lucida (Cycadales). Australian Journal of Botany, 55, 592-600.

Tilman, D., May, R.M., Lehman, C.L. \& NowaK, M.A. (1994) Habitat destruction and the extinction debt. Nature, 371, 65-66.

URBAN, M.C. (2015) Accelerating extinction risk from climate change. Science, 348, 571-573.

Valiente-Banuet, A., Aizen, M.A., Alcántara, J.M., Arroyo, J., Cocucci, A., Galetti, M. et al. (2015) Beyond species loss: the extinction of ecological interactions in a changing world. Functional Ecology, 29, 299-307.

Violle, C., Navas, M.-L., Vile, D., Kazakou, E., Fortunel, C., Hummel, I. \& Garnier, E. (2007) Let the concept of trait be functional! Oikos, 116, 882-892.

Vovides, A.P. (1990) Spatial distribution, survival and fecundity of Dioon edule (Zamiaceae) in a tropical deciduous forest in Veracruz, Mexico, with notes on its habitat. American Journal Botany, 77, 1532-1543.

Wardle, D.A., Barker, G.M., Bonner, K.I. \& Nicholson, K.S. (1998) Can comparative approaches based on plant ecophysiological traits predict the nature of biotic interactions and individual plant species effects in ecosystems? Journal of Ecology, 86, 405-420.

Williams, D.G., Hultine, K.R. \& Dettman, D.L. (2014) Functional trade-offs in succulent stems predict responses to climate change in columnar cacti. Journal of Experimental Botany, 65, 3405-3413.

YÁñez-Espinosa, L. \& Flores, J. (2016) Effects of shade on germination traits of the endangered cycad Dioon edule (Zamiaceae). Botanical Sciences, 94, 127-132.

Yánez-Espinosa, L, Flores, J., Millán, P.S.R. \& Méndez, G.R. (2014) Influence of germination date on Dioon edule (Zamiaceae) seedling tolerance to water stress. Journal of Plant Research, 127, $413-422$. 